\title{
Money and Marriage in Jane Austen's Pride and Prejudice
}

\author{
Sariwulandari ${ }^{1 *}$ \\ ${ }^{1}$ Department of English Language Studies, Universitas Hasanuddin, Makassar, Indonesia \\ *sarideen@gmail.com
}

\begin{abstract}
This research aims at finding out (1) Austen's view about marriage in Pride and Prejudice (2) Jane Austen and the Female condition in the eighteenth century of England through the novel (3) the relationship between marriage and money in "Pride and Prejudice" by Jane Austen. This research is descriptive research that implies library research by collecting the library materials like taking notes from books, internet, dictionary and other documents which are related to the topic. The data of this research is the primary data i.e. Pride and Prejudice novel and the secondary data, i.e., the references that are related to the topic. The data was analyzed by using a structuralism genetic method. This analyzed the literary works from intrinsic and extrinsic elements of the work. The result of this research indicated about (1) Austen's view about marriage in "Pride and Prejudice" they are marriage for economical reason, marriage between upper and middle class, marriage for real love, (2) Jane Austen and the female condition in the eighteenth century of England through the novel, they are (a) The importance of marriage for women (b) financial pressure to Marry (c) Restriction placed on women. (3) The relationship between marriage and money.
\end{abstract}

Key words: Aspiration, attractiveness, nineteenth century, woman position.

\section{Introduction}

Nineteenth century England had some serious social problem left over the heyday of royalty and nobility. One of the most significant of these was the tendency to marry for money. In this basic equation, a person sought a spouse based on the dowry receivable and their allowance [1]. This process went both ways; a beautiful woman might be able to snag a rich husband, or a charring handsome man could woo a rich young girl. In this marriage, money was only the consideration. Love was left out, with a feeling that it would develop, as the years went by.

Jane Austen's Pride and Prejudice gives critic about the economic underpinnings of social relations, especially marriage. With great irony and wit Austen shows how the tenders' human feelings interact with and are influenced by financial considerations [2]. It is an acknowledge truth in England particular society that a single woman without a fortune must need a husband who has one [3]. In the world of this novel, marriage is a market. And the young women are its merchandise.

The economics of marriage have changed over time. Historically, in many cultures the family of the bride had to provide a dowry to pay a man for marrying their daughter. In other cultures, the family of the groom had to pay a bride price to the bride's family for the right to marry the daughter. In some cultures, dowries and bride prices are still demanded today[4]. 
The objectives of research are to find out the Austen's presentation of marriage in Pride and Prejudice, to find out the female condition in the eighteenth and nineteenth century of England through the novel, and to find out about the relationship between marriage and money in Pride and Prejudice.

\section{Theoritical Reviews}

The Genetic-Structuralism approach refers to genetic factors in understanding the literary works. The genetic is the history of the literary works and some experts believe that there are a number of factors related to the history reality that influences the work before it was created. Goldman points out: that the works have to be started in structural analysis by understanding the intrinsic elements in the works. Structure significant that researcher has to be analyzed sociefically in order to find some important values in the works, means represents the world view of the authors (vision du monde) [5]. In this case, an author is not as individual but the representatives of this society.

\section{Methodology}

The writer used the intrinsic approach in analyzing the novel. Which is the way to approach the work which is based on the internal factors and their various levels, and external factors. The research was library research, which uses descriptive method. Descriptive method is intended to describe everything related to the topic of the research. In this case, the writer described the relationship between marriage and money in Pride and Prejudice.

\section{Data Sources}

The primary data is in the Pride and Prejudice. The supporting data is the information that relevant and related to the topic which could be reached through books, journals, and internet.

\section{Collecting Data Method}

The technique of data collection is divided into few steps as follows; Doing a closed reading toward the primary data, I Making notes or remark about all problems, other supporting ideas of the novel, and intrinsic elements related to the main objectives. Making formulation of problems and other supporting ideas based on the focus or the study. Collecting the related then making a classification of them according to the objectives of the study. Analyzing the data and trying to cover the all scope of problems that have been formulated in the first chapter. Recollecting and concluding the result of the study or analysis.

\section{Data Analysis}

Intrinsic approach: In this case the writer analyzed from the intrinsic elements of the novel. The intrinsic elements of the novel are characterization, theme, plot, setting, and point of view.

Extrinsic approach: The second approach the writer analyzed the social background of the literary work. In this case are the background of the writer and the history when the literary work was made [6].

\section{Findings and Discussion}

\section{Intrinsik Element}

\section{Characterization}

1. ane Bennet - The eldest and most beautiful Bennet sister. Jane is more reserved and gentler than Elizabeth. The easy pleasantness with which she and Bingley interact contrasts starkly with the mutual distaste that marks the encounters between Elizabeth and Darcy.

2. Charles Bingley - Darcy's considerably wealthy best friend. Bingley's purchase of Netherfield, an estate near the Bennets, serves as the impetus for the novel. He is a genial, well-intentioned gentleman, whose easygoing nature contrasts with Darcy's initially discourteous demeanor. He is blissfully uncaring about class differences.

3. Mr. Bennet - The patriarch of the Bennet family, a gentleman of modest income with five unmarried daughters. Mr. Bennet has a sarcastic, cynical sense of humor that he uses to purposefully irritate his wife. Though he loves his daughters (Elizabeth in particular), he often fails as a parent, preferring to withdraw from the never-ending marriage concerns of the women around him rather than offer help.

4. Mr. Bennet's wife, a foolish, noisy woman whose only goal in life is to see her daughters married. Because of her low breeding and often unbecoming behavior, Mrs. Bennet often repels the very suitors whom she tries to attract for her daughters. 
5. Lydia Bennet - The youngest Bennet sister, she is gossipy, immature, and self involved. Unlike Elizabeth, Lydia flings herself headlong into romance and ends up running off with Wickham.

6. Mr. Collins - A pompous, generally idiotic clergyman who stands to inherit Mr. Bennet's property. Mr. Collins's own social status is nothing to brag about, but he takes great pains to let everyone and anyone know that Lady Catherine de Bourgh serves as his patroness. He is the worst combination of snobbish and obsequious.

7. Lady Catherine de Bourgh - A rich, bossy noblewoman; Mr. Collins's patron and Darcy's aunt. Lady Catherine epitomizes class snobbery, especially in her attempts to order the middle-class Elizabeth away from her well-bred nephew.

8. Mary Bennet - The middle Bennet sister, bookish and pedantic

Theme

The theme of marriage a is set in the very opening sentences of Pride and Prejudice"

"Its truth universally acknowledged, that a single man in possession of a good fortune, must be in want of wife"

This is Austen's way of implying that a single man in possession of a good fortune is automatically destined to be the object of desire for all unmarried women. The statement opens the subject of the romantic novel; courtship and marriage. The sentence also introduces the issue of what the reasons for marrying are. She implies here that marry for money.

Plot

\section{Beginning}

The beginning of the novel describes Mrs, Bennet family excitement over the arrival of a single man "of considerable fortune: in the neighborhood. The residents of Hertfordshire are excited by the news a wealthy single gentleman named Mr. Bingley has rented Netherfield Park, a large house with extensive grounds. Mrs. Bennet urges her husband to go meet Mr. Bingley when he arrives in the neighborhood so that their five daughters may then have opportunity to meet the gentleman and attract his interest.

Climax

Mr. Darcy's proposal to Elizabeth.

Ending

The novel ends on the hopeful note of two Christmas-time weddings for the eldest Bennet daughters. Elizabeth builds a friendship with Darcy's sister Georgiana, occasionally sends money to Lydia, and gradually moves her husband to reconcile with his aunt. By their actions and their shared sense of duty, Elizabeth and Darcy is a union of the gentry and the aristocracy, they show themselves to have become leaders in their society. [7]

\section{Setting}

Setting of Place is Longbourne, in rural England and Setting of Time is Some point during the Napoleonic Wars (1797-1815).

\section{Point of View}

The novel is primarily told from Elizabeth Bennett's point of view.

\section{Discussion}

\section{Jane Austen's View About Marriage}

In Jane Austen's time, courtship was a central and absolutely necessary convention. Family and marriage created a public and central position in the social and economic measures of English society.[8]In this novel, marriage is seen as an institution that both determines and is determined by history. It was involved with the social continuation of the family line through inherited property and with the making of social classes. Women were expected to have a dowry, provide by their parents or saved by themselves, which was to be given to your husband. For this reason, and a variety of others, only thirty percent of women married. It was no use to the women of this time to wait for their parents to die so ultimately, they had to buy themselves a husband. Women inherited only through their husbands so they were practically born poor, and stayed poor, and lived well only by their husband's favor. That is why the state of marriage fell upon the responsibility of the female in the choice of her husband. This freedom of the English girl in courtship astonished many contemporary observers from other countries because to them marriages between reputable young people were usually arranged. This was done usually without any reference to the desires and wishes of the two people. Austen uses this novel and its characters to refute all previous views of marriage such as these and show society that marriage should be a unique moment of adventure, a time in a young girl's life where her destiny 
lay not in her family's hands but in her own. The novel Pride and Prejudice by Jane Austen is set in the 19th century where family respect and social differences were very important to everyone. This novel is a love story with various forms of marriage such as; marriage as and economic contract, marrying outside of your social class, marriage to a person whose personality and character are unequal to your own and marriage for love. Jane Austen has different opinions to each one of these reasons for getting marriage.

\section{Marriage for Economical Reason}

Throughout the book many forms of marriage are seen evident, one of the most obvious being marriage for economic reasons. What this means is that people in the nineteenth century especially women would get married for economic reasons such as to be able to have a decent house with something to eat.

"I am, to inherit this estate after the death of your honored father; I could not satisfy myself without resolving to choose a wife among his daughters." [7]

The second example is with he asking Charlotte to marry him, Charlotte very cleverly did this to be economically secured in life which was done very commonly this is shown by when it is described in the book how she started to plan how many years Mr. Bennett would be alive till Mr. Collins could inherit the estate. Jane Austen's opinion on this topic is that she does not view it as a thing she would want to do but at times such as expressed through Charlotte you have to be realistic and take into account your economic situation because it was seldom to marry a rich man of a much higher class than your own.

\section{Marriage Between Upper and Middle Class}

Another major sort of marriage which occurs in this novel is the one concerning marrying outside your social class which happens twice in the novel. This is when someone from a rather high class marries a village girl would be considered a social disaster. This is demonstrated by Mr. Darcy's first marriage proposal towards Elizabeth, which he says:

"In vain have I struggled. It will not do. My feelings will not be repressed. You must allow me to tell you how ardently I admire and love you." [7]

Which shows the risk, which he is taking on asking of some one of a much lower class. Families would take very dramatic actions to stop a male member from making this mistake, because it would not do any good for the family. Lady Catherine who does not want her nephew to marry someone of a lower class shows this particular action. Another example of how marrying outside of your social class was considered a bad thing is shown by Mr. Darcy telling his friend Mr. Bingley that Marrying Jane is not in his best interest due to her lower class. Jane Austen's opinion towards this sort of marriage is certainly that it wasn't good for the family but it still would be Mr. Darcy and Mr. Bingley did the right thing if it was for true love like. It is undoubtedly Jane Austen's opinion because she portrays her opinion through the main characters, which are Elizabeth and Jane Which both marry out of their social class.

\section{Unequal Marriage}

There is marriage to a person whose personalities and character are unequal to your own is also various times throughout the novel. Examples to address this style of marriage would be Mr. Bennett and his marriage with Mrs. Bennett, this marriage is not a good one because he can no longer respect her shown in numerous occasions such as when he teases his wife because it pleases him shown in the seen when he tells Elizabeth to do the opposite of what her mother want referring to Mr. Collins proposal. We can also tell Mr. Bennett is unhappy of his marriage because of what he tells Elizabeth: superior" [7]

"But let me advise you to think better of it... I know you could be neither happy nor, you looked up to him as a

Shows how he does not want Elizabeth making the same mistake as he did with Mrs. Bennett. Example of this manner of marriage would be Charlotte and Mr. Collins who do not respect each other especially Charlotte who only want Mr. Collins to be away from the house as much as possible because she does not want to be with him. Jane Austen's appears to be that she does not thing this is a very pleasant site into marriage and she also expresses that somebody shouldn't marry if he/she does not respect her/his partner otherwise he/she won't be happy like Charlotte.

\section{Jane Austen's and the female condition in the eighteenth century of England}

For women, making the best marriage possible was of utmost importance. Their financial future, as well as their position in society depended on it (single women were often deemed mentally ill). During the early nineteenth century women married relatively late, as a family would wait until the daughter had completed her education and perfected her accomplishments.[9]

The Importance of Marriage of Woman. For women, making the best marriage possible was of utmost importance. Their financial future, as well as their position in society depended on it (single women were often deemed mentally ill). During the early nineteenth century women married relatively late, as a family would wait until the daughter had completed her education and perfected her accomplishments.[9] Once this was the case, a relative or close family 
friend would 'out' the lady during the season, perhaps traveling to the capital or one of the fashionable spa towns, such as Brighton or Bath, where they would act as chaperone and introduce a lady to society.

It was common practice during Austen's time for a woman to find a husband to save her from spinsterhood or to gain financial security. Austen viewed this as a type of prostitution and disapproved of it. Pride and Prejudice dramatizes this form of women inequality and show that women who submits themselves to this type of marriage will be a suffer as Charlotte did in the novel;

When Mr. Collins said anything of which his wife might reasonably be ashamed, which certainly wasn't unseldom, she (Elizabeth) would involuntarily turned her eye on Charlotte. Once or twice, she could discern a faint blush; but in general Charlotte wisely did not hear." [7]

Financial Pressure to Marry. "It is a truth universally acknowledged that a single man in possession of good fortune must be in want of a wife" [9]

In Jane Austen's time, courtship was a central and absolutely necessary convention. Family and marriage created a public and central position in the social and economic measures of English society. In this novel, marriage is seen as an institution that both determines and is determined by history. It was involved with the social continuation of the family line through inherited property and with the making of social classes. Women were expected to have a dowry, provide by their parents or saved by themselves, which was to be given to your husband. For this reason, and a variety of others, only thirty percent of women married. It was no use to the women of this time to wait for their parents to die so ultimately, they had to buy themselves a husband. Women inherited only through their husbands so they were practically born poor, and stayed poor, and lived well only by their husband's favor. That is why the state of marriage fell upon the responsibility of the female in the choice of her husband. This freedom of the English girl in courtship astonished many contemporary observers from other countries because to them marriages between reputable young people were usually arranged [10]. This was done usually without any reference to the desires and wishes of the two people.

Actually, Austen, a systematic ironist, meant that a single woman, in the late eighteenth and early nineteenth centuries, was in want of a man with a good fortune. In Austen's little world, marriage

Restrictions Placed on Women. In addition to financial pressures, the severe restrictions laws and customs of eighteenth and nineteenth century England placed on women made women look to marriage as a means of stability and made women even more dependent on men. For instance, inheritance laws entailed a family's inheritance to a male heir.[9]

"I'm, to inherit this estate after the death of your honorable father, I could not satisfy myself without resolving to choose a wife among his daughters." [7]

In the situation of the Bennet family in Pride and Prejudice, Mr. Bennet's inheritance, his money and his home, Longbourn House, would have gone to Mr. Collins, his cousin, leaving his wife and five daughters poor and homeless upon his death.

\section{The Relationship Between Money and Marriage}

Marriage and money were inextricably linked to power and inheritance. It was a world where her husband owned a married woman's fortune legally. The feudal laws of primogeniture meant that a daughter could not inherit her father's estate, and if her father died without a male heir, his wife and daughters would have to move out of the family. The inheriting male heir might be a very distant relation, and perhaps completely unknown to the widow and her daughters. If a lady came from the super-rich aristocracy, a father could pay for an act of parliament, which would allow his daughter to inherit his wealth, with her husband taking the family name. This was however extremely rare.

In Pride and Prejudice, we always see country squires' leisurely life with calls, walks, picnics conversations, parties' balls, and marriage. But seeing the through the surface, there is a world of struggling for existence determined by economic base. The whole books talked about money.

Mr. Bennett's property consists almost entirely in an estate of thousand and pounds a year. Mrs. Bennett's father leaves her four thousand pounds. Each of their five daughters can get one thousand pounds in the 4 percent after mother dies.

Mr. Bingley inherits property to the amount of nearly a hundred thousand pounds from his father and he has four or five thousand a year. Miss Bingley has a fortune of twenty thousand pounds.

Mr. Darcy has ten thousand pounds as a year whiles his sister; Georgiana has a property of thirty thousand pounds. Wickham wants to get ten thousand from Darcy, otherwise he will not marry Lydia even though they are in elopement.

Colonel Fitzwilliam, Darcy's cousin, would like to marry a woman who should have a property of at least fifty thousand pounds, since he has no inheritance as a younger son of an earl.

To make it clear that money is very important in the marriage convention of such kind of society, Mr. Collins' words after Elizabeth refusing his proposal can be taken as proof.

"It does not appear to me that my hand is unworthy your acceptance, or that establishment I can offer would be any other than highly desirable. My situation in life, my connections with the family of de Bourg h, and my relationship to 
your own, are circumstances highly in my favor; you should take it into further consideration, that in spite of your manifold attractions, it is by no means certain that another offer to marriage may ever be made you, your portion is unhappily so small, that it will in all likelihood undo the effects of your loveliness and amiable qualifications." [7]

His attention of choosing Elizabeth as his wife, his plan of amends of atonement for inheriting their father's estate; and he thinks it an excellent one, full of eligibility and suitableness, and excessively generous and disinterested on his own part. Therefore, he takes it for granted that Elizabeth will accept his proposal cheerfully and readily. Though Elizabeth rejects him for his incomplete character, it still can tell us the low social status of the British women at that period. The only thing a young lady without property could do is to marrying a man with a good fortune.

Similar with Charlotte thinking about marriage have to consider about money such in her statement;

"... when you have had time to think it all over, I hope you will be satisfied with what I have done. I am not romantic, you know, I never was. I ask only a comfortable home; and considering Mr. Collins character, connections, and situation in life. I am convinced that my chance of happiness with him is a fair, as most people can boast on entering the marriage state." [7]

Charlotte's is fully conscious of her motives when she accepts Mr. Collins, she is aware that she is unlikely to get a better, or indeed any other, offer of marriage. It is a realistic choice in a world where marriage is the only career for woman in charlotte's social position.

\section{Conclusion}

Jane Austen shows that the likely consequence of a marriage based on mere personally like, wealth, and class factors can produce only misery and shame. She also makes it clear that a woman should be able to choose her husband for herself. Austen breaks the ideals and morals of the society during her time by showing that is it wrong to make marriage an economic investment, and that love should be the basis of any relationship.

Throughout the novel we can clearly see Jane Austen's view of marriage in the 19th century. It is clearly shown through the carefully chosen characters and their situation. Jane undeniably approves with two sorts of marriage the first and most patent is for love, shown by how it is the final marriage at the end of the book causing a happy ending and especially because it concerns the main characters. The other second style of matrimony would be the one for an economic contract which it is certain that she does not like but Jane Austen shows that in real life this would be the most wises one for her time period, this is shown by how Charlotte Lucas marries Mr. Collins showing due to her being a smart respectable woman that this was a very intelligent thing to do. The reasons for marriage in the 19th century have not changed greatly from the ones there are now such as marriage as an economic contract it is not so much for the money because women can work now to gain it but for prestige connection of value. Marrying outside your social class isn't seen as much for family respect and money but it is still not well seen in certain areas for racial differences and differences in nationalities. Marriage to a person whose personality is unequal to your own is still seen many times and will never stop happening, marriage for love will also stay the same even though at times it might be infrequently seen but it will always be happening.

Jane Austen took a "stratified society absolutely for granted and examined the female powerlessness that underlined monetary pressure to marry," the injustice of eighteenth and nineteenth century laws and customs, and the suppressed individualism of females. Through her novels, Austen gave a voice to the women of her time, and, in doing so, gave a voice for the society in which she lived. But, Austen's own voice was not lost among the others; she spoke loud and clear in the outcome of her stories because, despite the existing female condition, and Pride and Prejudice overcame society's barriers by marrying for love instead of money or future well-being, by expressing their true selves, and by asserting the small amount of freedom that they were allowed, all of which society considered to be appropriate behavior, all of which Jane Austen considered to be essential to a happy and fulfilling life, and all of which are relevant to women even today.

The writer suggests making another analysis of Jane Austen novel Pride and Prejudice in other aspect because Jane Austen theme described the real-life women and the pressure around them in the eighteenth century of England. This novel gives us some values especially in choosing partners in our live, that consequence of a marriage based on mere personally like, wealth, and class factors can produce only misery and shame.

\section{Acknowledgements}

The big support regarding the paper goes to all research sample in the study as well as the research location SMP Muhammadiyah Parepare.

\section{References}

[1] George. (2007). Marriage In The Eighteenth Century Of England [Online]. Available: https ://humboldt . edu . com 
[2] Sparknotes. (2007). Biography of Jane Austen [Online]. Available: https://sparknotes . com/janeausten

[3] M. H. Srayoshah, Victorian Women in Literature, RSP, vol. 54, pp. 141-150, 2017.

[4] The New Encyclopedia Britannica, vol. 3, 10, 11. London: Encyclopedia Britannica, 1982.

[5] M. Zimmerman, Lucien Goldmann, Genetic Structuralism and Cultural Creation in Capitalist World. Santiago: Bravo y Allende, 2006.

[6] Encarta. (2017). The Elements of Novels [Online]. Available: https ://encarta.msn.com

[7] J. Austen, Pride and Prejudice. London: Puffin Books, 1995

[8] S. Ylivouri, Women and Politeness in Eighteenth Century England. London: Routledge, 2019.

[9] O. Bernier, The Eighteenth-Century Woman. New York: The Metropolitan Museum of Art, 1981.

[10] N. Arif and I. Fatima, Marital Satisfaction in Different Types of Marriages, Pakistan Journal of Social and Clinical Psychology, vol. 13 no. 1, pp. 36-40, 2015. 